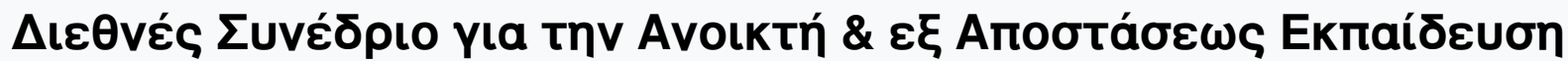

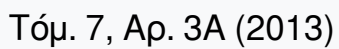

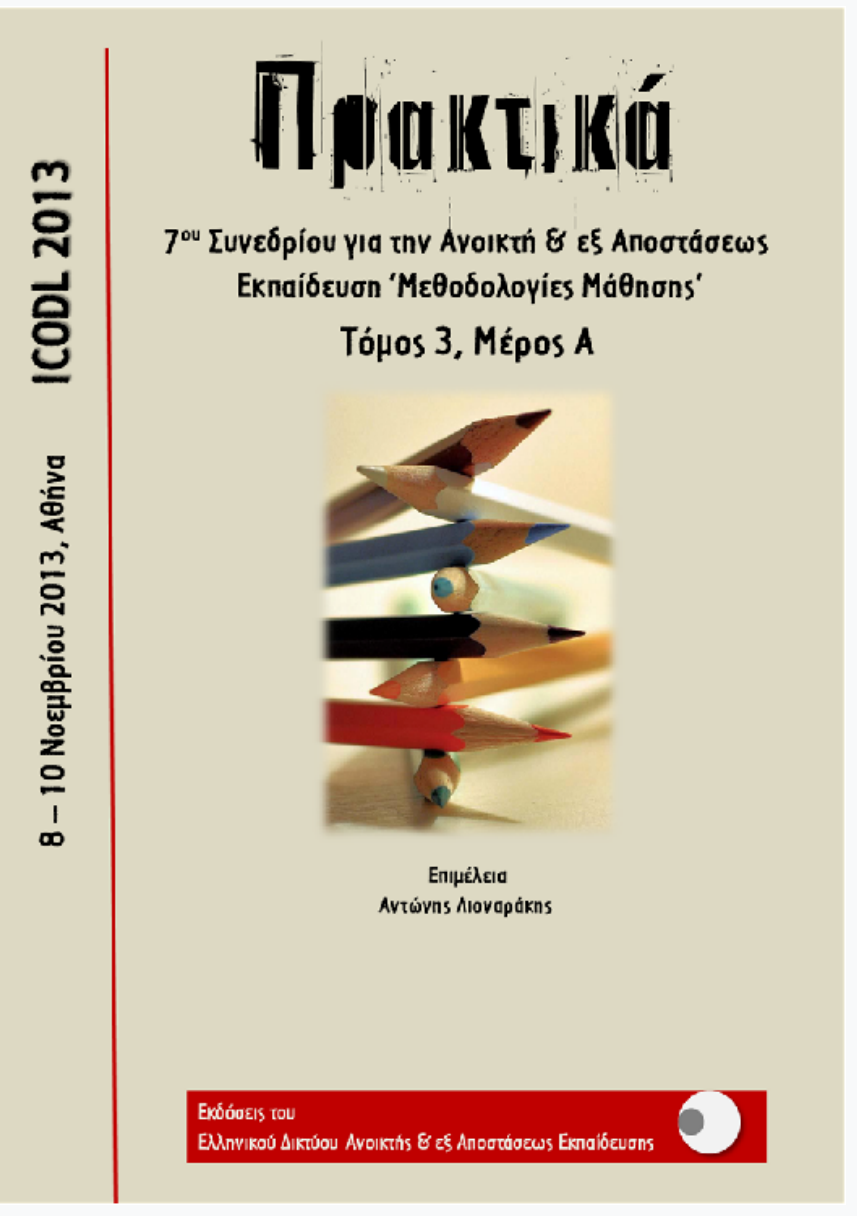

Tralning teachers in competence based education - the TRANSIt use case in Greece

Katerina Riviou, Sofoklis Sotiriou

doi: $10.12681 /$ icodl. 602 


\title{
TraIning teachers in competence based education - the TRANSIt use case in Greece
}

\author{
Katerina Riviou \\ Ellinogermaniki Agogi, R\&D Department \\ kriviou@ea.gr
}

Sofoklis Sotiriou

Ellinogermaniki Agogi, R\&D Department sotiriou@ea.gr

\begin{abstract}
The key competence acquisition (KCA) by every young person is one of the long term objectives of the updated strategic framework for European cooperation. Most of the EU Member States are formulating and at least beginning to implement policies that move their school systems from being predominantly input led and subject-oriented towards curricula which include competences, cross-curricular activities, active and individual learning, as well as a focus on learning outcomes. Yet, these developments do not necessarily result in significant, widespread changes in practice - that is, in how schools actually organise and provide learning experiences for pupils. The difficulty is in all cases translating these policies into practice. TRANSIt is a European project that aims to contribute to the enhancement of transversal key competences of students through building teachers capacity for competence oriented education. This paper presents the outcomes from the needs analysis survey on key competence acquisition (KCA) in Greece, which took place during the period June July 2013 in which 648 responses were collected.
\end{abstract}

Key-words: Competences, transversal competences, assessment of competences, competence-based learning, lifelong learning, ePortfolios

\section{Introduction}

Key competence acquisition (KCA) is one of the long term objectives of the updated strategic framework for European cooperation (Official Journal of the European Union, 2009). The concept of key competence originated with the adoption of the Lisbon Strategy in 2000 and it resulted in the European Reference Framework (European Commission, 2006). Key competences in the EU framework are those that 'all individuals need for personal fulfillment and development, active citizenship, social inclusion and employment'. The Framework identifies and defines 8 key competences:

1. Communication in the mother tongue;

2. Communication in foreign languages;

3. Mathematical competence and basic competences in science and technology;

4. Digital competence;

5. Learning to learn;

6. Social and civic competences;

7. Sense of initiative and entrepreneurship;

8. Cultural awareness and expression; 
The last 5 competences are considered transversal. Most of the EU Member States are beginning to implement policies that move their school systems from being predominantly subject-oriented towards curricula which include competences, active and individual learning, as well as a focus on learning outcomes. One such example is Greece, where in the school year 2012-2013, pilot curricula for competence driven education have been introduced. In Austria however, the promotion of holistic teaching methods has been supported at policy level for several years. In other countries (e.g. France, Netherlands) innovative policies are already embedded in national strategy documents and in some cases these have already led to major structural changes, such as the introduction of new qualifications frameworks or the reform of the curriculum around the Key Competences (European Commission, 2009a). In general, there are a variety of different models of competences in European countries (European Commission/EACEA/Eurydice, 2012).

Yet, these developments do not necessarily result in significant, widespread changes in practice - that is, in how schools actually organise and provide learning experiences for pupils. The difficulty is in all cases translating these policies into practice. One of the core problems for the effective implementation of the above policies is the lack of initial education and training, as well as systematic support of teachers. One more obstacle regarding KCA is the lack of effective assessment practices. Assessment of competence is one of the vehicles that can be used to support teachers in making this paradigm shift (Black, \& William, 1998). This places new demands on the competences of teachers and trainers and therefore on the structure and content of initial and continuing teacher education (European Commission, 2009b). "TRANSIt - TRANSversal key competences for lifelong learning: TraIning teachers in competence based education" approach aims to support teachers at bridging the gap between policy and practice on a European scale.

In this paper we present the overall aims and methodological approach of the "TRANSIt" project, the current state of Competence-Based Learning (CBL) policy and practice in Greece, and the results from the needs analysis study in Greece with the goal to deliver an effective training programme for teachers.

\section{TRANSIt project}

The aim of the "TRANSIt" project is to have a positive impact on the development of students' competencies by building teachers capacity, in line with the EU objectives; thus prioritising the improvement and quality of teacher education to have a direct effect upon levels of students KCA (Official Journal of the European Union, 2007). To achieve this, a pilot teachers training methodology will be developed on the didactics and e-assessment of key transversal competences. The methods of the project are founded on a holistic view of students learning, going beyond subject boundaries and finding application in a wide spectrum of curriculum subjects. The TRANSIt approach contributes to the development of creativity, intercultural and multilingual competences, social development, and "learning to learn" competences. TRANSIt aims to contribute towards the improvement of the quality of competence education by improving teachers' awareness and professional skills regarding the didactics and e-assessment of the key competences with the use of ePortfolios, and supporting them to bring European and national policies into practice. The impact of the training material will be assessed by authentic assessment methods analysing qualitative and quantitative characteristics of user-generated open educational resources (OER) content uploaded in the TRANSIt e-portfolios environment. 
The overall approach taken towards delivery of the training is based on the methodological principles of participatory design with the user groups in the development of the training framework; that means systematically analysing the state of the art and target groups' needs. To this end, stakeholders' needs analysis was performed in order to identify the obstacles in the process of introducing new approaches in teaching practice and to identify enablers that will effectively support such interventions. The results will be analysed in next sessions.

The training programme will include extended cycles of school - centered activities aimed at getting teachers feedback about their experiences gained in the classroom during the implementation of the proposed activities - developing the training in cycles through: a) workshops/seminars conventional and online and b) schoolcentered work where teachers will implement suggested training activities in their own classrooms making it possible to investigate the initial impact.

The training framework will be developed in a modular format according with the peculiarities of each partner country and the needs of the user groups, thus catering for the localisation of the approach. A systematic evaluation methodology will be developed in order to identify the impact of the proposed approach in terms of efficiency and effectiveness of the training process - using key performance indicators (KPIs) for measuring the efficiency of teacher training.

The key to effective professional development is finding a way to organise qualified teachers, so they can collaborate with their colleagues, therefore TRANSIt will develop a respective community of practice. Finally, a common set of guidelines in the didactics and assessment of competence driven education will be constituted.

\section{Current state of Competence-Based Learning in Greece}

In this section we focus on specific aspects about current policy and practice regarding Competence Based Learning (CBL) activities in Greece. CBL activities are defined here as educational activities aimed to students' KCA. First, we give an overview of the features from the educational system that may have an impact in current practice of CBL. Then, we explain the results of the needs analysis.

\subsection{Policy}

The method by which competences/key competences have been introduced in the education system varies among countries. Some have introduced these approaches through adaptations of the curriculum, whilst others have done it through legislative change (Gordon, et al. 2009). Greece is such an example, where in the school year 2012-2013, pilot curricula for competence driven education based on the National Life Long Learning Strategies for the 'New School' of the Greek Ministry of Education, Life Long Learning and Religious Affairs have been introduced (http://dschool.edu.gr/). Regarding assessment of students in Key competencies currently five countries among them Greece do not administer any national tests in compulsory education (European Commission/EACEA/Eurydice, 2012).

\subsection{Needs analysis of Competence-Based Learning from teachers in Greece}

This section aims to analyse the feedback provided by the target groups of the project from Greece (teachers (in-service, pre-service), teacher trainers, educational policy makers) in the online survey. It aimed to gather feedback for the needs analysis through the relevant questionnaire deployed. 


\subsubsection{Methodology}

The analysis of the project's target groups' questionnaires was carried out by the use of descriptive statistical analysis (tables and graphical visualisation). For the statistical analysis and the creation of the graphs Microsoft Excel was used, as well as the functions available in the open source software LimeSurvey. This software was also used for the online Greek questionnaire that was made available to interested stakeholders.

The questionnaire was aimed at identifying the profiles of the possible participants in TRANSIt training activities, the current implementation of competence-based didactics and assessment as well as participants training needs. Results on the questionnaire are outlined below. The link for the survey was made available through the etwinning mailing list by the National Contact Service, CTI Diophantus.

\subsubsection{Survey on needs analysis on CBL}

648 responses were collected in total. The collection of this data took place during June-July 2013. In the next pages the most important facts and figures from the survey are presented. There is commentary on each set of graphs and tables. From a total of 648 questionnaires, 236 were fully completed, which is a very satisfactory result, since the questionnaire was quite extended and some of the teachers are not familiar with competences.

\section{User profile}

From the total of 648 that participated in the survey, $196(30 \%)$ were men and 452 (70\%) were women with the majority in the age range of 41 to 55 years old $(62,81 \%)$. All participants were related to the field of Education. The majority of respondents are teachers in secondary education $(74,80 \%)$ and teachers in primary education $(48,60 \%)$. The next group of participants with highest representation are School leaders $(11 \%)$, Teachers' trainers $(10,40 \%)$, Pre-service Teachers with percentage of $3,60 \%$, Curriculum developers and Educational Policy Makers (1\%), each, whereas other roles were $3,40 \%$. Among them persons responsible for environmental centers, responsible of counseling centers for students, career counselors, adult trainers or researchers/PhD candidates).

The majority of respondents have a more than 15 years' experience in their profession $(43,83 \%)$. The qualification of respondents is Degree $(50,31 \%)$, Masters $(41,67 \%)$ and $\mathrm{PhD}(7,10 \%)$. Only $0,93 \%$ had just the teaching qualification. Regarding usage of ICT, the highest percentage defines themselves to be Enthusiastic on the use of ICT $(56,64 \%)$ while those claiming to have taken part in continuing professional development (CPD) activities on the theme of competence acquisition was $(55,25 \%)$. Reviewing the descriptions provided on these training activities, there is of a wide and varied spectrum, but mostly around technology enhanced learning. Training varies from Level 1 ICT training program- "In-Service Training of Primary and Secondary School Teachers on Information and Communication Technology (ICT). Basic Skills in Education", Level 2 ICT training program - "Teachers' Training in the Use and the Exploitation of ICT in the Educational Teaching Process", creative writing/thinking in class, use of Web2.0/social media tools, training for implementing projects, creative drama activities/creativity techniques and in-service training activities. In the training special needs is also mentioned, and there are respondents who feel that the available training opportunities are not enough, especially for the regional parts of the country. 


\section{Current implementation of didactics and assessment of key competences}

Throughout the survey, participants reflected on their own competence on teaching and assessing transversal key competences. Participants graded the level of their experience in teaching digital competence, learning to learn, social and civic competences, sense of initiative and entrepreneurship, and social and cultural awareness. Grading was done in a scale from "none" to "more than 3 years".

Overall, the majority of participants graded their knowledge and skills in teaching all competences, between the ranges of 1 and more than 3 years (Fig. 1). Participants feel most confident about teaching digital competence (49\%); this competence has also the biggest deviation of values. In contrast, participants claim that they have the least experience in teaching the sense of initiative and entrepreneurship; a percentage of $41 \%$ claim to have no relevant experience.

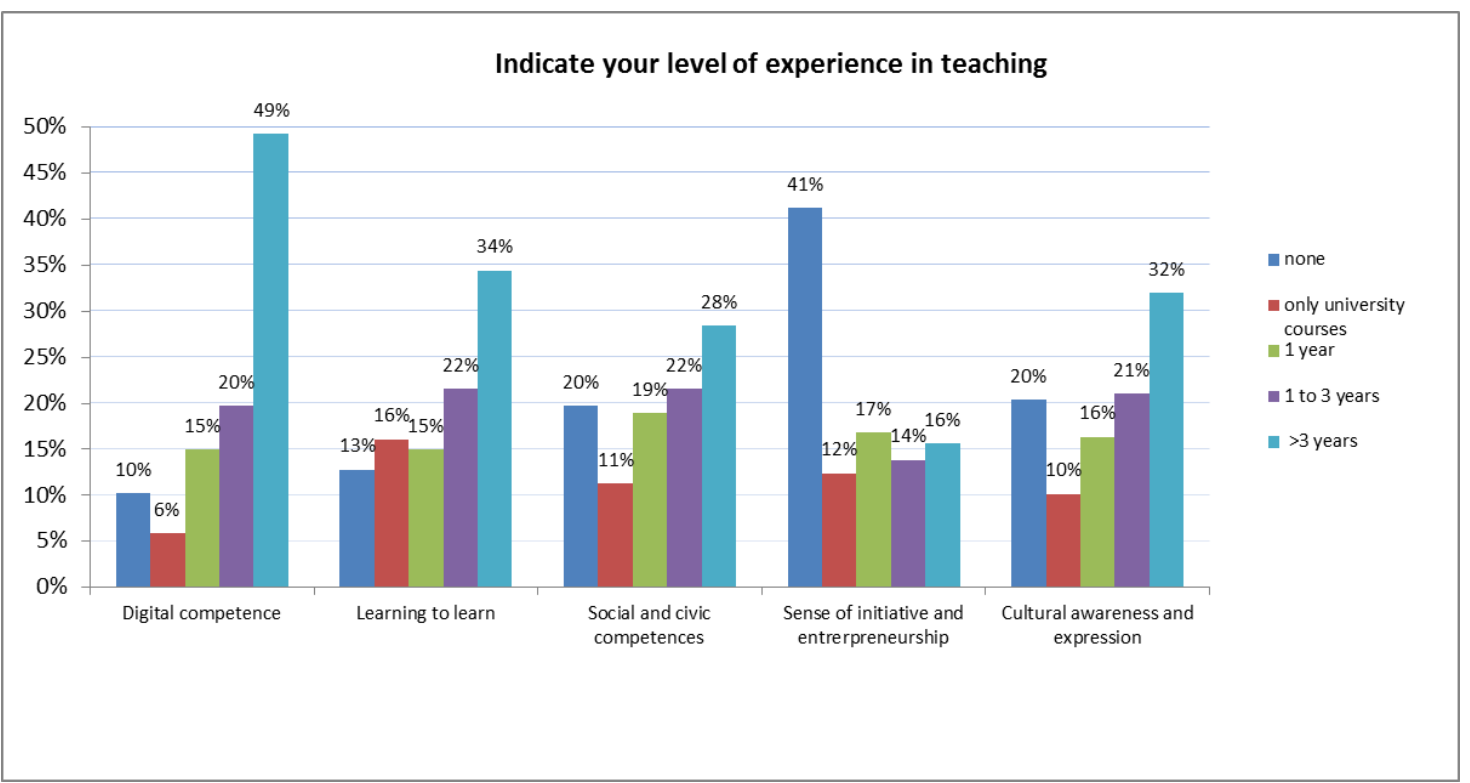

Fig. 1: Distribution of answers regarding level of experience in teaching transversal key competences

Regarding a description of the general steps that teachers take, when planning a crosscurricular lessons that promotes KCA for their students, a high percentage $(71,5 \%)$ answered to the open question. A common pattern was that teachers try to elicit the level of their students and their individual interests, define in collaboration with them the subject that they will work on, the educational aims, divide the students in' teams and then they assign the tasks. Teams are guided and facilitated by the teacher and as final step results are composed and presented in class. A great percentage of participants refer to collaboration with colleagues for the design and implementation of cross-curricular projects, showing its importance.

Data was also gathered about participants' use of didactics and teaching methods (Fig. 2). The most used method is Discussion and debating (25\%). The second most used method is (Sub)group activities (18\%). Interviewing experts, peers or others is the method with the most extreme distribution of answers, i.e. teachers tend to use it very often or never use it. 


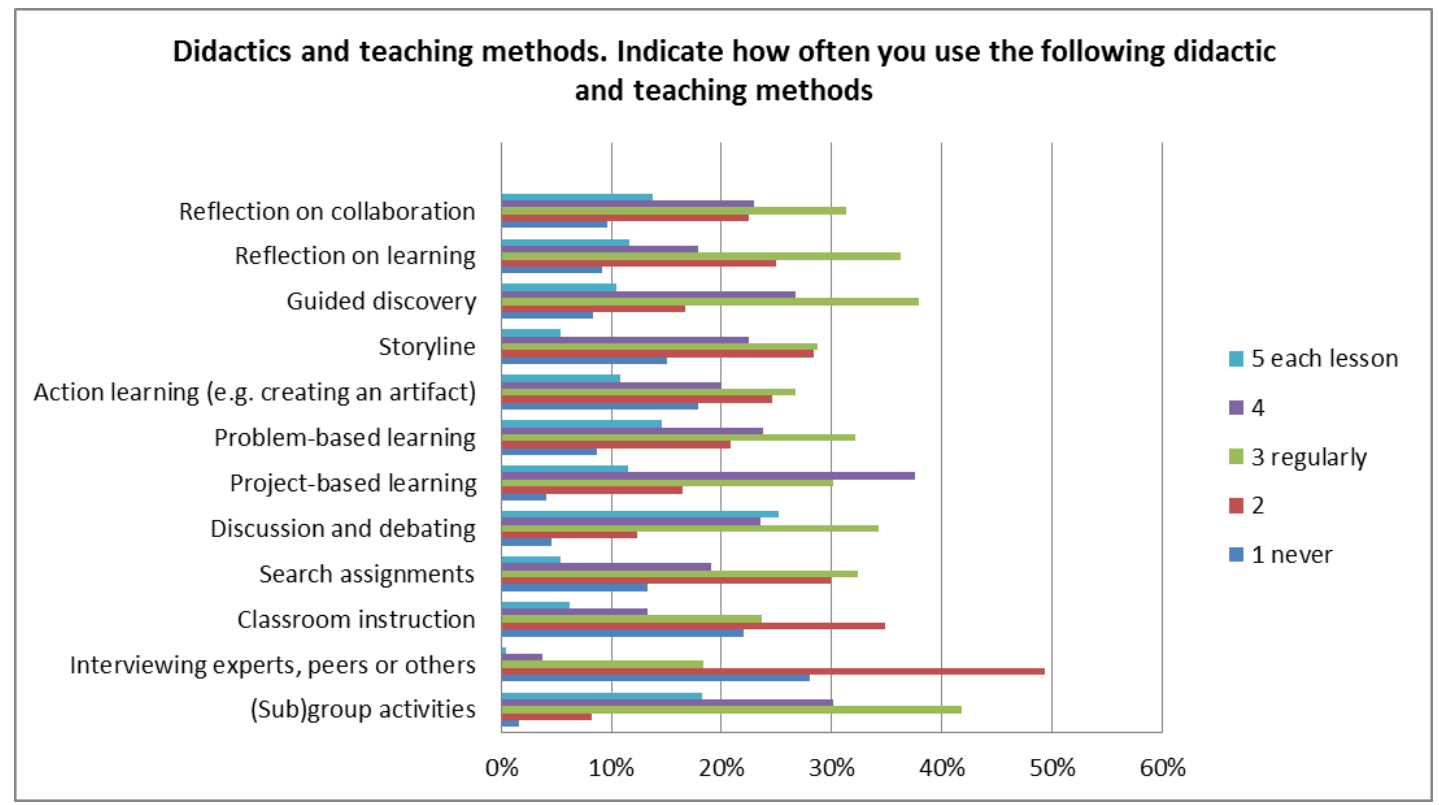

Fig. 2: Distribution of answers regarding teaching methods in competence based learning

Regarding the technologies used during the planning and implementation of CBL (Fig. 3), the technologies with the most deviation are Software authoring tools and LMS, with Software authoring tools being the tools with highest percentage of none use $(56,69 \%)$, and LMS following with 50,59\%.

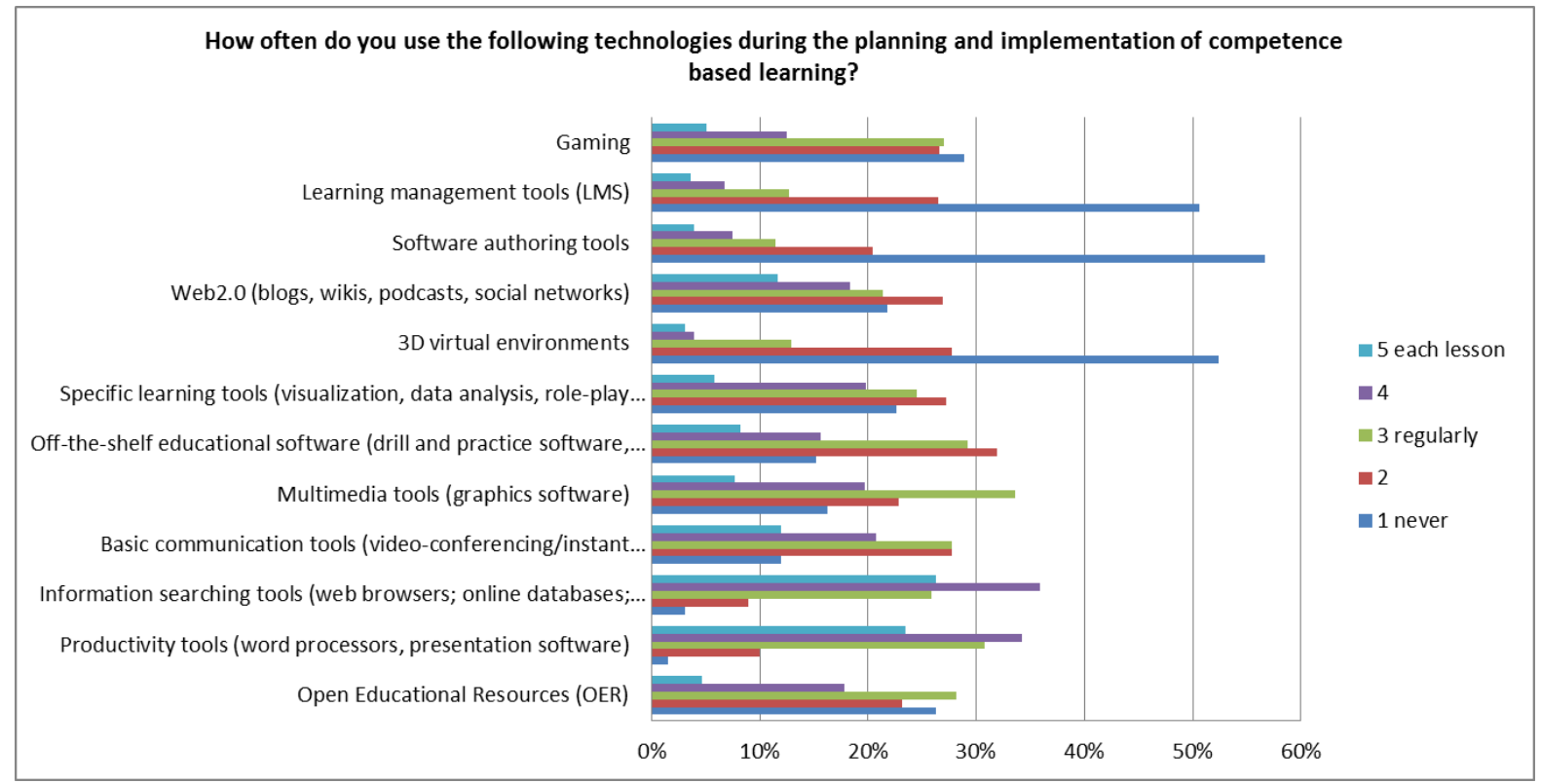

Fig. 3: Distribution of answers regarding technologies used for competence based learning

Regarding the assessment tools/methods that teachers have mostly used or other stakeholders (school managers/administrators) claim that are used at schools, ePortfolios and Rubrics have the lowest levels of use specifically for assessment purposes with percentages of $57 \%$ and $52 \%$ respectively (Fig. 4). In general, teachers who implement CBL activities report a lack of knowledge about competence-based assessment techniques. This means that teachers mostly perform concept-based evaluation of CBL activities. 


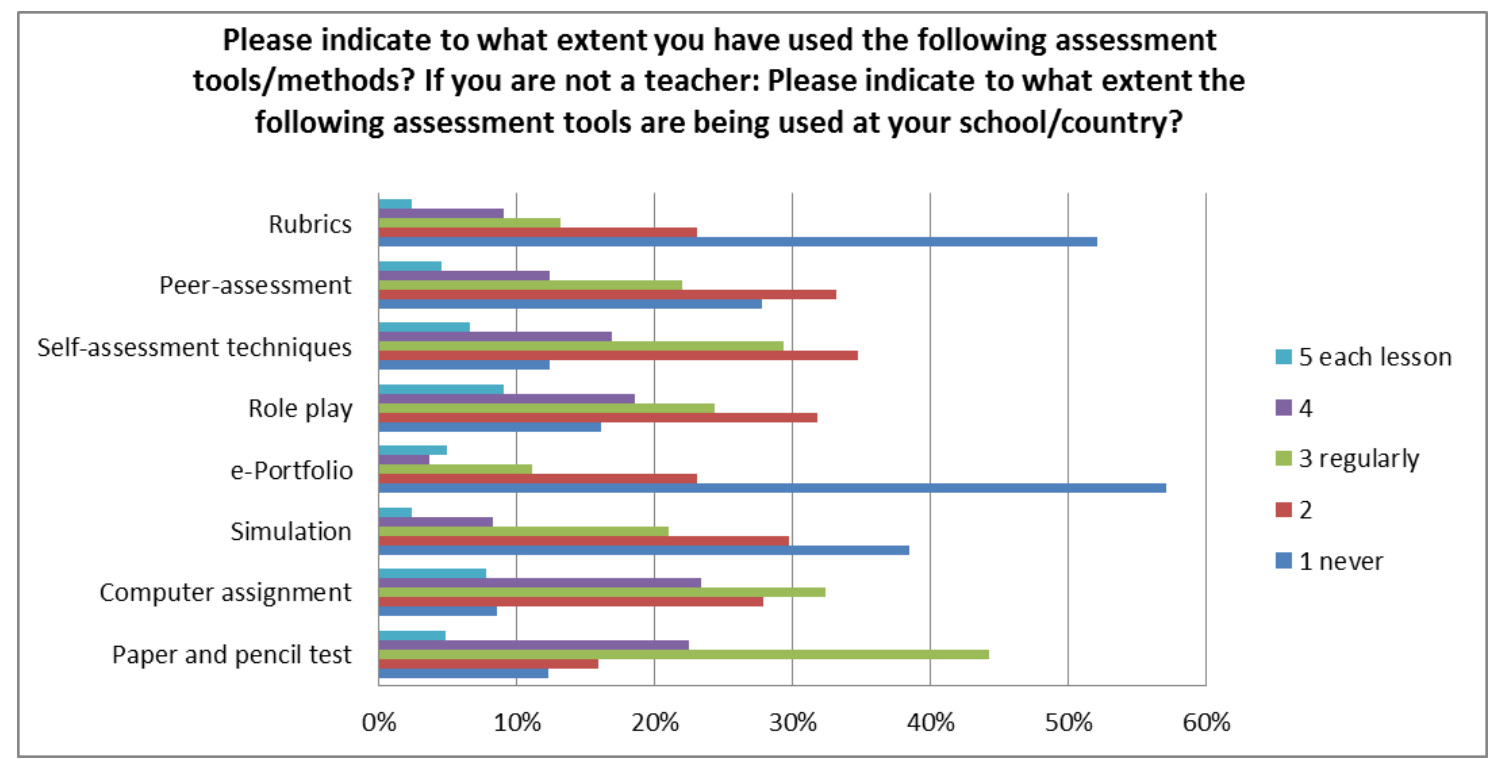

Fig. 4: Assessment tools/methods used for CBL

\section{Limitations of school practice}

Participants spot several constraints to the systematic implementation of transversal CBL activities. They feel their working schedule doesn't allow for the educational innovation they would like, the most frequent answer being time constraints.

The low availability of resources such as a computer room and a very limited flexibility to use them has also been mentioned among the biggest barriers encountered.

\section{Curriculum opportunities for applying CBL}

Given the constraints, participants identified enablers to the implementation of CBL activities. As participants indicated CBL is usually implemented in the classroom $(20,75 \%)$ and not in extra-curricular activities. A percentage of $23,55 \%$ indicates that CBL is usually implemented with the implementation of specific projects (Fig. 5).

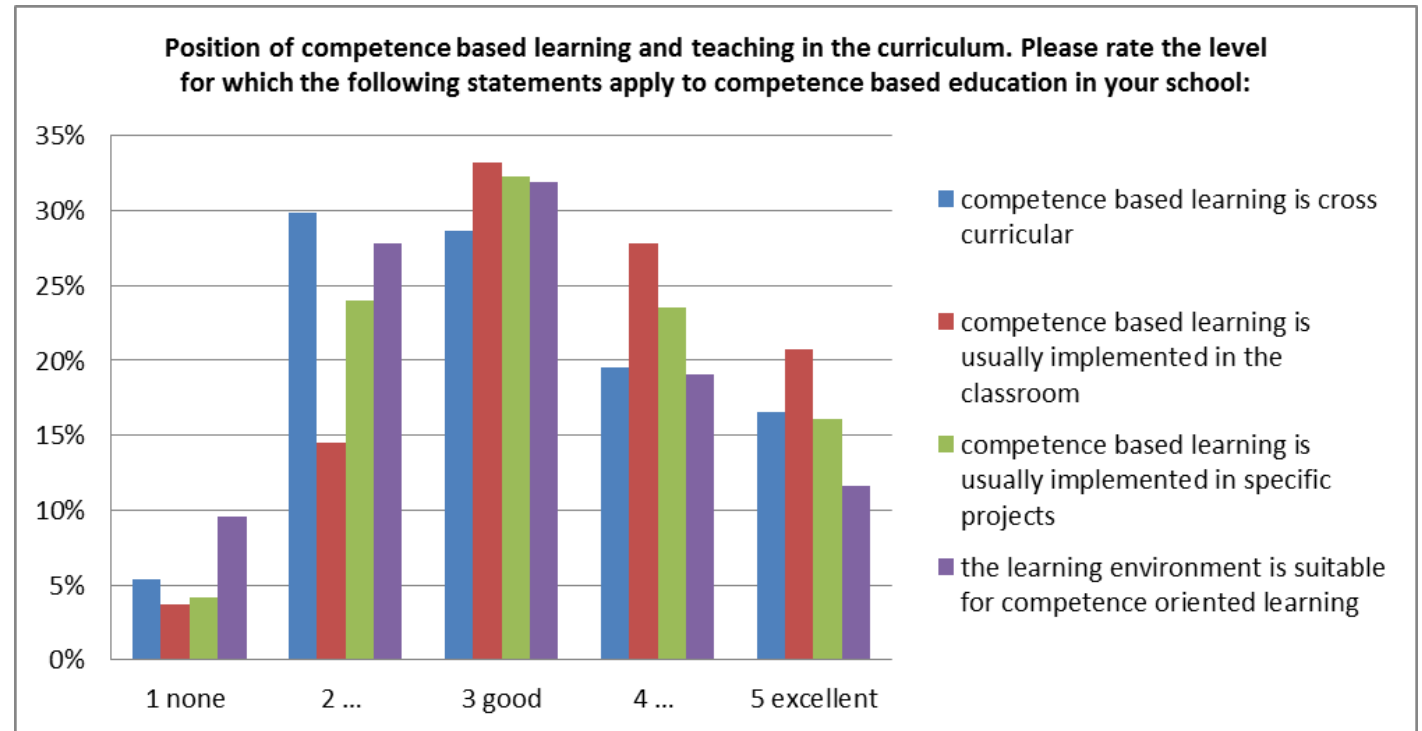

Fig. 5: Position of competence based learning and teaching in the curriculum. Please rate the level for which the following statements apply to $\mathrm{CBL}$ in your school 


\section{Training needs}

Participants were asked to grade their training needs on various topics, covering underpinnings and specificities of transversal key competences, competence-based didactics and assessment and teacher professional development, among others (Fig. 6).

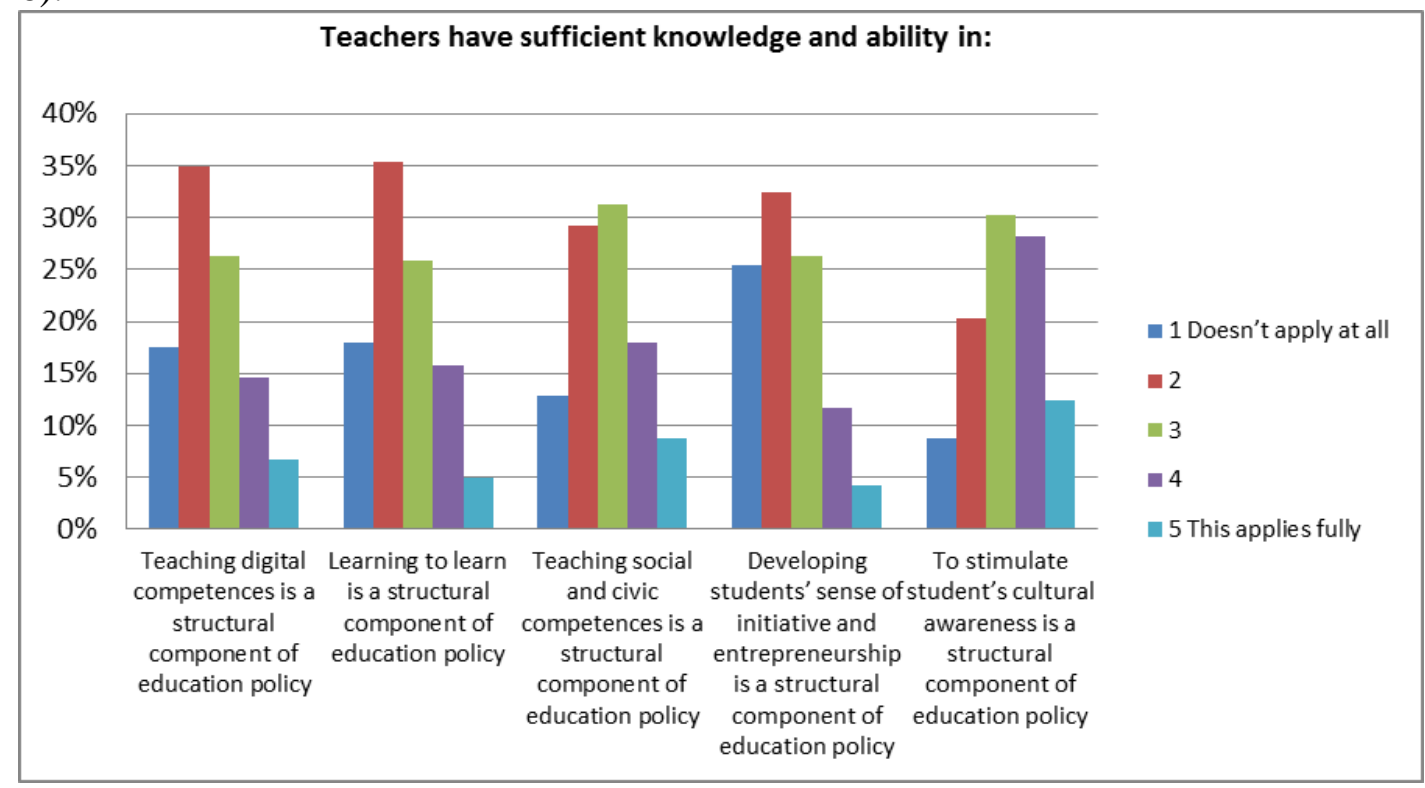

Fig. 6: Transversal key competences: experience and education policy - Teachers have sufficient knowledge and ability in...

Data on training needs is consistent with the current implementation of competencebased didactics and assessment. The most important item for them is "Didactics and teaching methods" and most particularly regarding the themes applied throughout competences: critical thinking, creativity, initiative, problem solving, risk assessment, decision taking, and constructive management of feelings. The second most required training need is in competence-based assessment $(41,62 \%)$. Particularly, participants are interested in learning about specific tools to assess the transversal key competences (Fig. 7).

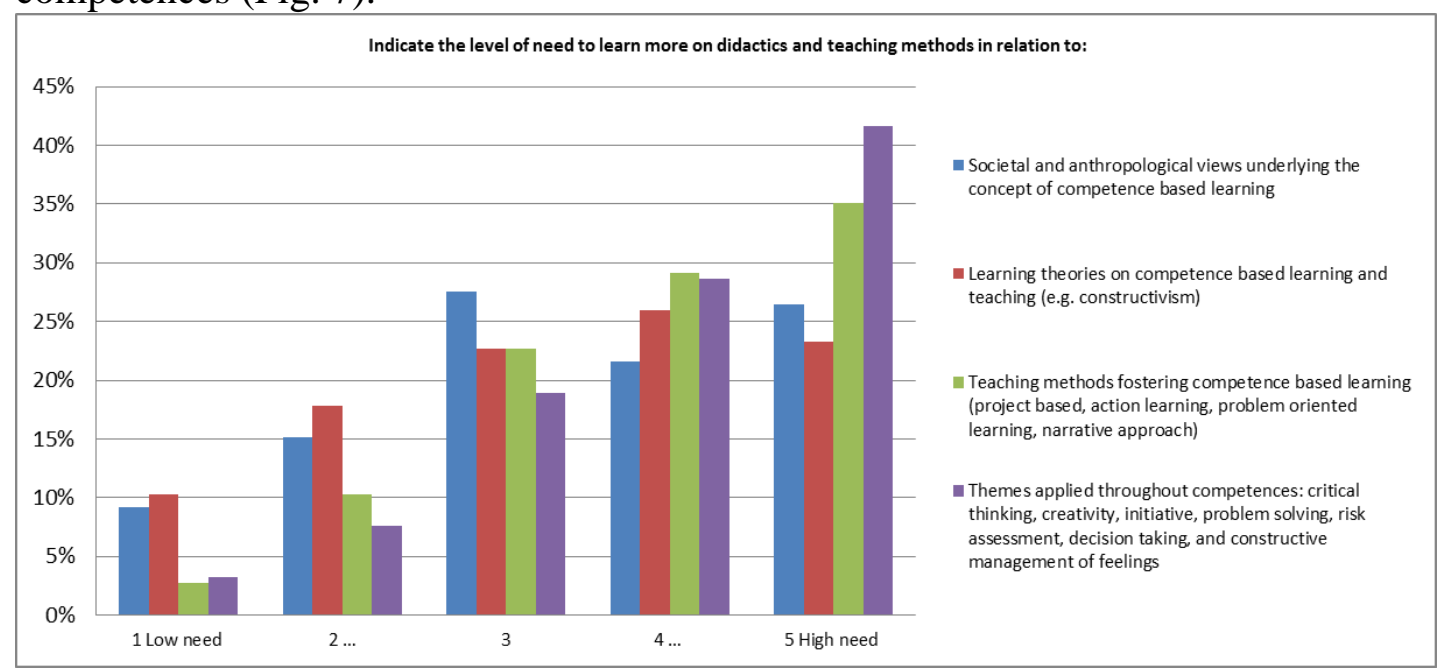

Fig. 7: Training needs regarding competence based education

Regarding the needs for the activities/methods to be incorporated in training workshops, participants expressed their high interest primarily for Demonstrations of tools and instruments $(60,80 \%)$, then Practical assignments $(56,20 \%)$ and then 
Examples of good practices $(53,90 \%)$, demonstrating the need of teachers to undertake hands-on training, which can have a direct impact in their daily teaching practice as well as practical support (Fig. 8).

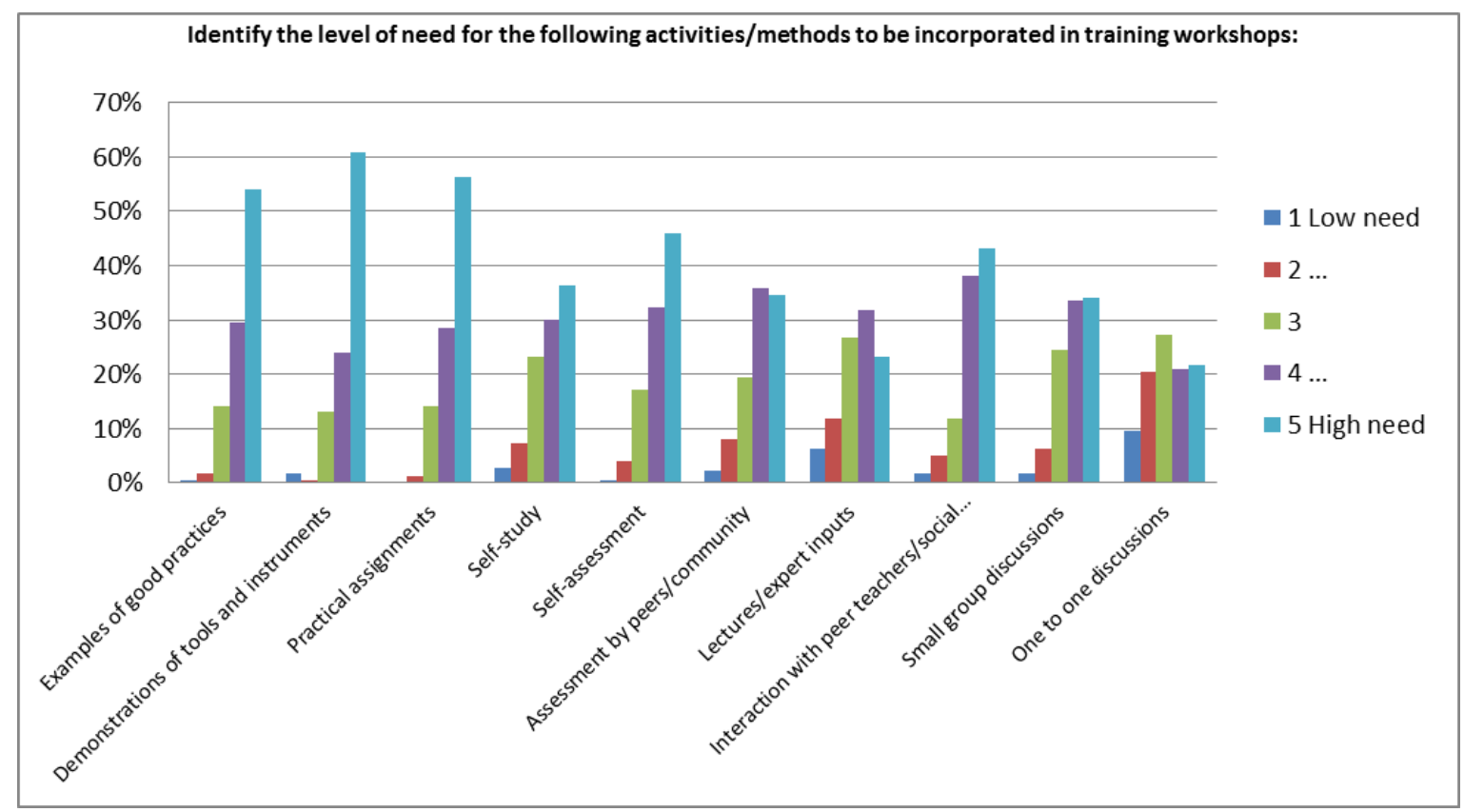

Fig. 8: Activities/Methods to be incorporated in training workshops

\section{Conclusion and recommendations}

In general, the EU is prioritising the improvement of the quality of teacher education so as to have a direct effect upon levels of students' acquisition of competences. Therefore, the professional development of teachers and their training is a key requirement for the way forward (European Commission, 2010).

Our needs analysis confirms that, given the limitations imposed by the official curriculum in Greece, teachers are generally motivated to make a paradigm shift towards competence-based teaching. This is indicated by the high percentage (95\%) of participants in the needs analysis study that have provided their contact details in order to be informed about the project's training and piloting activities.

The profile of the participants demonstrates that there is a strong interest especially by secondary education teachers to get trained. This is aligned with the literature findings that the situation is even worse for teachers of secondary education since their training has not prepared them for the most part for holistic methods and cross-curricular teaching, although primary teachers may have more expertise in multidisciplinary CBL approaches (European Commission, 2009a).

The majority of respondents has been in this profession for more than 15 years and has a rather high qualification framework, which demonstrates a constant need of teachers for in-service training.

The preference of teachers and school leaders to learn primarily from demonstration of tools and instruments, practical assignments and examples of good practices, demonstrates the need of stakeholders to undertake hands-on training, and that teachers need support in their everyday practice (training, institutional support, specific examples/good practices). This can be explained since they probably face difficulties in translating the policy into teaching practice, especially when they don't have the proper underpinnings. Participants also express the need to get trained regarding the themes of initiative and entrepreneurship, as well as regarding 
competence based assessment. Regarding school managers/administrators they are also willing to support teachers by expressing their need for professional development on how to create a work and learning environment for teachers to allow them develop competence based teaching skills. TRANSIt will try to address the training needs indicated with an emphasis on assessment methods and tools, also by taking into consideration the report by Redecker (2013).

Collaboration and exchange of practices needs to be encouraged through training, since participants refer to the benefits of collaboration. Therefore the creation and support of teachers' communities of practice is of crucial importance. The creation of a social networking platform where teachers will be able to exchange and co-create their cross-curricular educational scenarios fostering students' competences is an imperative and synergies will be examined with other projects in order to achieve this goal, such as Open Discovery Space project. TRANSIt is at the phase of designing its environment with use of open source tools, as well as the Open Badge Infrastructure, as a mechanism for accrediting teachers in their community, as well as students KCA.

\begin{abstract}
Acknowledgement
The TRANSIt: TRANSversal key competences for lifelong learning: TraIning teachers in competence based education project (528005-LLP-1-2012-1-GR-COMENIUS-CMP) [www.transit-project.eu] has been funded with support from the European Commission. This publication reflects the views only of the author, and the Commission cannot be held responsible for any use which may be made of the information contained therein.
\end{abstract}

\title{
References
}

Black, P. \& William, D. (1998). Inside the Black Box: raising standards through classroom assessment, London: School of Education, King's College, Retrieved 7 October 2013 from: http://weaeducation.typepad.co.uk/files/blackbox-1.pdf

European Commission/EACEA/Eurydice (2012). Developing Key Competences at School in Europe: Challenges and Opportunities for Policy. Eurydice Report. Luxembourg: Publications Office of the European Union, ISBN 978-92-9201-292-2, doi:10.2797/93204, Retrieved 7 October 2013 from: http://eacea.ec.europa.eu/education/eurydice/documents/thematic reports/145EN.pdf

European Commission (2006). Key competences for Lifelong Learning - European Reference $\begin{array}{lllll}\text { Framework. } & \text { Retrieved } & 7 & \text { October } & 2013\end{array}$ http://ec.europa.eu/dgs/education_culture/publ/pdf/ll-learning/keycomp_en.pdf

European Commission (2009a). Education and Training 2010 Work Programme, Final Report. Cluster Key Competences-Curriculum Reform Peer Learning Activity "Fostering Cross-curricular Key Competences for Creativity and Innovation”, Vienna 10-12 November 2008, Local Cultural Policies Handbook: Retrieved 7 October 2013 from: http://www.kreativinnovativ09.at/fileadmin/EuDocs/Vienna\%20PLA\%20final\%20version\%2 0Jan\%2026th.pdf

European Commission (2009b). Education and Training 2010 Work Programme, Assessment of key competences, Joint seminar of the Peer Learning Clusters 'Key Competences', 'Teachers and Trainers', 'Maths, Science and Technology', and 'Learning Outcomes', 15 October 2009, Brussels, EU. $\quad$ Retrieved 7 October 2013 from: http://www.euroclio.eu/download/2009/Assessment\%20seminar\%2015\%200ct2009\%20final\%20report\%20.doc

European Commission (2010). Cluster Key Competences - Curriculum Reform Report, Peer Learning Activity "Implementation and Assessment of Key Competences", Prague Czech Republic, 811 December 2009, Final 07042010, Retrieved 7 October 2013 from: http://www.kslll.net/Documents/PLA_KC_Prague final\%20report.pdf

Gordon, J. Halasz, G.. Krawczyk, M Leney, T. Michel, A. Pepper, D. Putkiewicz E., Wisniewski J. (2009). Key Competences in Europe: Opening Doors For Lifelong Learners across the School 
Curriculum and Teacher Education, CASE Network Reports, No. 87, Retrieved 7 October 2013 from: http://ec.europa.eu/education/more-information/doc/keyreport_en.pdf

Official Journal of the European Union (2007). Conclusions of the Council and of the Representatives of the Governments of the Member States meeting within the Council of 15 November 2007, on improving the quality of teacher education (2007/C 300/07). Retrieved 7 October 2013 from: http://eurlex.europa.eu/LexUriServ/LexUriServ.do?uri=OJ:C:2007:300:0006:0009:EN:PDF

Official Journal of the European Union (2009). Council conclusions of 12 May 2009 on a strategic framework for European cooperation in education and training ('ET 2020'). (2009/C119/02): $\begin{array}{llll}\text { Retrieved } & 7 & \text { October } & 2013\end{array}$ http://eurlex.europa.eu/LexUriServ/LexUriServ.do?uri=OJ:C:2009:119:0002:0010:EN:PDF

Redecker, C. (2013). The Use of ICT for the Assessment of Key Competences, 25891 EN, Retrieved 7 October 2013 from: http://ipts.jrc.ec.europa.eu/publications/pub.cfm?id=5719 